Ewa Pogorzata

\title{
KONTROWERSJE WOKÓŁ NAUCZANIA JĘZYKA NIEMIECKIEGO JAKO JĘZYKA MNIEJSZOŚCI NARODOWEJ W POLSCE \\ PO 1989 ROKU - PODTRZYMYWANIE TOŻSAMOŚCI NARODOWEJ CZY NAUKA JĘZYKA OBCEGO
}

\section{Uwagi wstępne}

Od początku lat dziewięćdziesiątych XX wieku w polskim systemie oświaty możliwie jest pobieranie nauki języka niemieckiego jako języka mniejszości narodowej, przy czym język ten nauczany jest także jako jeden z języków obcych. Nauka języka niemieckiego jako języka mniejszości organizowana jest przez szkoły dla osób posiadających obywatelstwo polskie i których rodzice/prawni opiekunowie złożą wniosek o organizację takiego nauczania. Niestety wiąże się to z pytaniami, na ile nauczanie to de facto służy podtrzymywaniu tożsamości narodowej, a nie jest tylko nauką języka obcego.

W latach dziewięćdziesiątych duże kontrowersje budziło korzystanie z nauki języka niemieckiego przez osoby narodowości polskiej. W ostatnich latach najbardziej znanym konfliktem była sprawa szkoły w Kędzierzynie-Koźlu, przejętej przez Stowarzyszenie Oświatowe Koźle Rogi. We wrześniu 2014 roku spore kontrowersje wywołał artykuł opublikowany na łamach „Rzeczpospolitej” o znamiennym tytule Volks- 
lista w szkole na Opolszczyźnie?, którego autor postawił tezę, iż Polacy mają dodatkowe lekcje niemieckiego, jeśli podpiszą deklarację, że należą do mniejszości narodowej ${ }^{1}$. Podnosi się także kwestie związane z wysokością środków finansowych, przekazywanych do jednostek samorządu terytorialnego na organizowanie nauki języków mniejszości.

Podstawą przeprowadzanych analiz były dane zastane. Przede wszystkim akty prawne, dane statystyczne, dokumentacja organów administracji publicznej, jak również źródła publicystyczne. Zastosowano podejście idiograficzne $\mathrm{z}$ wykorzystaniem analizy instytucjonalno-prawnej.

\section{Podstawy prawne organizowania i finansowania nauczania języka niemieckiego jako języka mniejszości narodowej}

Zapisy dotyczące możliwości nauki języka niemieckiego dla mniejszości niemieckiej w Polsce jako języka ojczystego znalazły się w traktacie między Rzecząpospolitą Polską a Republiką Federalną Niemiec o dobrym sąsiedztwie i przyjaznej współpracy, podpisanym w Bonn w dniu 17 czerwca 1991 roku² $^{2}$ Zapisy traktatu weszły w życie z dniem 16 stycznia 1992 roku. Artykuł 21 stanowił „Umawiające się Strony będą na swych terytoriach chroniły tożsamość etniczna, kulturalną, językową i religijną grup wymienionych $\mathrm{w}$ artykule 20 ustęp $1^{3}$, oraz tworzyły warunki do wspierania tej tożsamości. [...] mimo konieczno-

1 A. Grabek, Volkslista w szkole na Opolszczyźnie?, 18 września 2014, http://www. rp.pl/artykul/1142024.html [dostęp: 21 grudnia 2014].

2 Dz.U. 1992, nr 14, poz. 56.

3 Art. 20 ust. 1: „Członkowie mniejszości niemieckiej w Rzeczypospolitej Polskiej, to znaczy osoby posiadające polskie obywatelstwo, które są niemieckiego pochodzenia albo przyznają się do języka, kultury lub tradycji niemieckiej, a także osoby w Republice Federalnej Niemiec, posiadające niemieckie obywatelstwo, które są polskiego pochodzenia, albo przyznają się do języka, kultury lub tradycji polskiej, mają prawo, indywidualnie lub wespół z innymi członkami swej grupy, do swobodnego wyrażania, zachowania i rozwijania swej tożsamości etnicznej, kulturalnej, językowej i religijnej bez jakiejkolwiek próby asymilacji wbrew ich woli. Mają oni prawo do pełnego i skutecznego korzystania z praw człowieka i podstawowych wolności bez jakiejkolwiek dyskryminacji i w warunkach pełnej równości wobec prawa" (ibidem). 
ści uczenia się oficjalnego języka odnośnego państwa, dążyć zgodnie z właściwymi przepisami prawa krajowego do zapewnienia członkom grup wymienionych w artykule 20 ustęp 1 odpowiednich możliwości nauczania ich języka ojczystego lub w ich języku ojczystym, w publicznych placówkach oświatowych, jak również tam, gdzie to jest możliwe i konieczne, posługiwania się nim wobec władz".

Stosowne zapisy dotyczące nauki języków mniejszości lub w językach mniejszości znalazły się w ustawie z dnia 7 września 1991 roku o systemie oświaty ${ }^{4}$, która weszła w życie z dniem 25 października 1991 roku. Artykuł 13 ustawy stanowił, iż „Szkoła i placówka publiczna umożliwia uczniom podtrzymywanie poczucia tożsamości narodowej, etnicznej, językowej i religijnej, a w szczególności naukę języka oraz własnej historii i kultury" ${ }^{\prime \prime}$ W ustawie zawarto delegację dla ministra właściwego do spraw oświaty i wychowania do wydania rozporządzenia w tej sprawie. W dniu 24 marca 1992 roku Ministerstwo Edukacji Narodowej (MEN) wydało rozporządzenie w sprawie organizacji kształcenia umożliwiającego podtrzymywanie poczucia tożsamości narodowej, etnicznej i językowej uczniów należących do mniejszości narodowych ${ }^{6}$. Dziesięć lat później zastąpiło je Rozporządzenie Ministra Edukacji Narodowej i Sportu z dnia 3 grudnia 2002 roku w sprawie warunków i sposobu wykonywania przez szkoły i placówki publiczne zadań umożliwiających podtrzymywanie poczucia tożsamości narodowej, etnicznej, językowej i religijnej uczniów należących do mniejszości narodowych i grup etnicznych ${ }^{7}$.

Na mocy ustawy z dnia 6 stycznia 2005 roku o mniejszościach narodowych i etnicznych oraz o języku regionalnym mniejszość niemiecka uznana została za mniejszość narodową. Mniejszością narodowa w rozumieniu ustawy, jest grupa obywateli polskich, która spełnia łącznie następujące warunki: (1) jest mniej liczebna od pozostałej czę-

\footnotetext{
4 Dz.U. 1991, nr 95, poz. 425 z późn. zm.

5 Tekst jednolity: Dz.U. 1996, nr 67, poz. 329 z późn. zm.

6 Rozporządzenie Ministra Edukacji Narodowej z dnia 24 marca 1992 roku w sprawie organizacji kształcenia umożliwiającego podtrzymywanie poczucia tożsamości narodowej, etnicznej i językowej uczniów należących do mniejszości narodowych (Dz.U. 1992, nr 34, poz. 150).

7 Dz.U. 2002, nr 220, poz. 1853.
} 
ści ludności Rzeczypospolitej Polskiej; (2) w sposób istotny odróżnia się od pozostałych obywateli językiem, kulturą lub tradycją (3) dąży do zachowania swojego języka, kultury lub tradycji; (4) ma świadomość własnej historycznej wspólnoty narodowej i jest ukierunkowana na jej wyrażanie i ochronę; (5) jej przodkowie zamieszkiwali obecne terytorium Rzeczypospolitej Polskiej od co najmniej 100 lat; (6) utożsamia się z narodem zorganizowanym we własnym państwie. Za mniejszości narodowe uznaje się następujące mniejszości: (1) białoruską (2) czeską; (3) litewską; (4) niemiecką; (5) ormiańską; (6) rosyjską; (7) słowacką; (8) ukraińską (9) żydowską.

Po przyjęciu ustawy o mniejszościach narodowych i etnicznych oraz o języku regionalnym zostało wydane Rozporządzenie Ministra Edukacji Narodowej z dnia 14 listopada 2007 roku w sprawie warunków i sposobu wykonywania przez przedszkola, szkoły i placówki publiczne zadań umożliwiających podtrzymanie poczucia tożsamości narodowej, etnicznej i językowej uczniów należących do mniejszości narodowych i etnicznych oraz społeczności posługującej się językiem regionalnym ${ }^{9}$.

W latach dziewięćdziesiątych organy prowadzące bądź organizujące nauczanie języków mniejszości otrzymywały subwencję oświatową zwiększoną o $20 \%$ na każdego ucznia pobierającego naukę języka ojczystego. Od 2002 roku wprowadzono dodatkową wagę 50\% dla mniejszych szkół. Dodatkowe środki naliczane były na podstawie danych zebranych na formularzu Głównego Urzędu Statystycznego (GUS) S-15 Sprawozdanie o nauczaniu jezzyka ojczystego w przedszkolach $i$ w szkołach dla dzieci i młodzieży mniejszości narodowych i grup etnicznych oraz organizacji nauczania uczniów pochodzenia romskiego na dzień 30 września danego roku ${ }^{10}$. Wysokość tych środków uzależniona jest od liczby uczniów objętych nauczaniem i zgłoszonych do Systemu Informacji Oświatowej. Corocznie MEN wydaje rozporządzenie w sprawie sposobu podziału

8 Dz.U. 2005, nr 17, poz. 141 z późn. zm.

9 Dz.U. nr 214, poz. 1579; tj. Dz.U. 2014, poz. 263.

10 Formularz GUS-u S-15: Sprawozdanie o nauczaniu języka ojczystego w przedszkolach i w szkołach dla dzieci i młodzieży mniejszości narodowych i grup etnicznych oraz organizacji nauczania uczniów pochodzenia romskiego, http://form.stat.gov.pl/formularze/form_s_05/doc/ S-15.rtf [dostęp: 21 grudnia 2014]. 
części oświatowej subwencji ogólnej dla jednostek samorządu terytorialnego. Od 2012 roku środki te zwiększane są odpowiednio o 20\% (waga P911), 150\% (waga P10), 110\% (P11 waga przejściowa między P9 i P10) i 40\% (waga P12 dla szkół prowadzących nauczanie w dwóch językach) w stosunku do tzw. standardu finansowego A, przypadającego na każdego ucznia.

\section{Stan nauczania języka niemieckiego jako języka mniejszości narodowej}

W okresie PRL-u szkoły z niemieckim językiem nauczania dla tzw. uznanych Niemców utworzone zostały na początku lat pięćdziesiątych XX wieku i funkcjonowały do wczesnych lat sześćdziesiątych. Placówki te stopniowo likwidowano w związku z wyjazdami ludności niemieckiej. Konsekwentnie natomiast ówczesne władze odmawiały tzw. ludności autochtonicznej/rodzimej możliwości nauki języka niemieckiego. Mimo iż zniesiono zakaz nauczania języka niemieckiego jako obcego na obszarze tzw. Ziem Odzyskanych, de facto jednak także w takiej formie nauki tego języka nie prowadzono ${ }^{12}$. W 1987 roku na łamach "Die Welt" ukazał się artykuł o znamiennym tytule "Język niemiecki dopiero od szkoły średniej. Ponad milion Niemców walczy o swą tożsamość", w którym była mowa o „czterech dziesięcioleciach polityki polonizacji ze strony władców z Warszawy”, braku możliwości rozwijania niemieckiej kultury i języka, obawach związanych z rozmawianiem po niemiecku na Śląsku, np. na ulicy, oraz braku możliwości uczenia się języka ojczystego w szkołach. Szacowano, że na Śląsku mieszkało

11 P9, P10 itd. - oznaczenie kolejnych wag w rozporządzeniach o podziale części oświatowej subwencji ogólnej.

12 E. Pogorzała, Nauczanie języka niemieckiego jako języka mniejszości narodowej we wspótczesnej Polsce, "Przegląd Narodowościowy” [w druku]. Ministerstwo Oświaty zniosło, ustanowiony w 1945 roku, zakaz nauczania języka niemieckiego w szkołach - jako języka obcego - zarządzeniem Ministra Oświaty z 26 lipca 1950 roku (Nr II Śr. - 2940/50) w sprawie nauczania języka niemieckiego w szkołach średnich ogólnokształcących (Dz. Urz. Ministerstwa Oświaty nr 14, poz. 176). Na temat szkolnictwa niemieckiego w latach pięćdziesiątych i sześćdziesiątych XX wieku w Polsce zob. szerzej: E. Pogorzała, Mniejszości narodowe i etniczne w polityce oświatowej państwa polskiego w latach 1944-1966, Zamość 2009, passim. 
wówczas 800 tys. Niemców z 1,1 mln zamieszkałych ogółem w Polsce. Stwierdzano także, że władze torpedują inicjatywy na rzecz wprowadzenia nauczania języka niemieckiego. Jako przykład podano postulat 50 uczniów i nauczycieli z Szombierek, którym odmówiono zorganizowania nauczania języka niemieckiego, powołując się na trudności finansowe ${ }^{13}$.

Dopiero w latach dziewięćdziesiątych w polskim systemie oświaty rozwinęło się na szeroką skalę zarówno nauczanie języka niemieckiego jako obcego, jak i jako języka mniejszości narodowej. W pierwszej dekadzie XXI wieku liczba uczniów pobierających naukę języka niemieckiego jako języka mniejszości ustabilizowała się na poziomie dwudziestu kilku tysięcy w szkołach podstawowych oraz ok. dziesięciu tysięcy w gimnazjach, które rozpoczęły działalność w roku szkolnym 1999 roku (zob. tabela 1).

Procentowe wskaźniki powszechności nauczania języka obcego mierzone są stosunkiem liczby uczniów uczących się danego języka do liczby uczniów ogółem. W latach 1991-1993 dominującym językiem był język rosyjski, drugą pozycję zajmował język angielski, a język niemiecki trzecią. W roku szkolnym 1992/1993 wskaźnik powszechności języka niemieckiego wynosił tylko $16 \%$, a języka rosyjskiego $34 \%$. W roku szkolnym 1996/1997 struktura powszechności nauczania języków obcych zmieniła się - język niemiecki zajął drugą pozycję po języku angielskim. Taka tendencja utrzymywała się w kolejnych latach. Wskaźnik powszechności nauczania języka niemieckiego jako przedmiotu obowiązkowego wzrastał równomiernie, osiągając wartość maksymalną 34,8\% w roku szkolnym 2002/2003. Przy czym najniższą wartość odnotowano na poziomie szkół podstawowych (od maksymalnie 20,7\% w roku szkolnym 2001/2002 do 10,7\% w 2009/2010). Na poziomie gimnazjów odpowiednio 43,2\% - 2001/2002 i 38,10\% - 2009/2010. Najwyższy wskaźnik powszechności nauczania języka niemieckiego - 70-80\% - odnotowano na poziomie szkół ponadgimnazjalnych (licea i tech-

13 Język niemiecki dopiero od szkoty średniej. Ponad milion Niemców walczy o swa tożsamość. Artykuł H. Krempa w "Die Welt” z 24 października 1987 r., w: J. Barcz (red.), Historyczne, polityczne i prawne aspekty tez RFN o niemieckiej mniejszości narodowej w Polsce. Część II: Wybór dokumentów, Warszawa 1988, s. 67-71. 
nika) ${ }^{14}$. Odwrotna tendencja natomiast ukształtowała się $\mathrm{w}$ zakresie nauczania języka niemieckiego jako języka mniejszości. Najwięcej dzieci uczy się na poziomie szkół podstawowych i gimnazjów, a na poziomie szkolnictwa ponadgimnazjalnego nauka nie jest kontynuowana.

\section{Tabela 1}

Nauczanie języka niemieckiego jako języka mniejszości narodowej w szkołach dla dzieci i młodzieży w latach 1992-2010

\begin{tabular}{|c|c|c|c|c|}
\hline Rok szkolny & $\begin{array}{c}\text { Szkoła } \\
\text { podstawowa }\end{array}$ & $\begin{array}{c}\text { Liczba uczniów } \\
\text { w szkole } \\
\text { podstawowej }\end{array}$ & Gimnazjum & $\begin{array}{c}\text { Liczba uczniów } \\
\text { w gimnazjum }\end{array}$ \\
\hline $1992 / 1993$ & 10 & 1307 & - & - \\
\hline $1993 / 1994$ & 31 & 3136 & - & - \\
\hline $1994 / 1995$ & 67 & 6152 & - & - \\
\hline $1995 / 1996$ & 111 & 10498 & - & - \\
\hline $1996 / 1997$ & 252 & 23050 & - & - \\
\hline $1997 / 1998$ & 265 & 25325 & - & 2588 \\
\hline $1998 / 1999$ & 267 & 28822 & - & 6148 \\
\hline $1999 / 2000$ & 273 & 25545 & 49 & 9967 \\
\hline $2000 / 2001$ & 269 & 24640 & 53 & 10823 \\
\hline $2001 / 2002$ & 256 & 26241 & 62 & 11269 \\
\hline $2002 / 2003$ & 261 & 26128 & 63 & 11391 \\
\hline $2003 / 2004$ & 254 & 24200 & 70 & 10974 \\
\hline $2004 / 2005$ & 256 & 24025 & 75 & 10524 \\
\hline $2005 / 2006$ & 263 & 24201 & 82 & 10249 \\
\hline $2006 / 2007$ & 268 & 24420 & 81 & 9460 \\
\hline $2007 / 2008$ & 264 & 24032 & 88 & 7946 \\
\hline $2008 / 2009$ & 267 & 23616 & 89 & \\
\hline $2009 / 2010$ & 274 & 23537 & & - \\
\hline
\end{tabular}

Źródło: Nauczanie języka niemieckiego w Polsce. Raport przegladowy 1990-2010 sporzadzony przez ORE na zlecenie MEN, Warszawa 2011, http://www.ore.edu.pl/phocadownload/edukacja_jezykowa/raport\%20polsko-niemiecki_all1.pdf, s. 25 [dostęp: 21 grudnia 2014].

14 Nauczanie języka niemieckiego w Polsce. Raport przegladowy 1990-2010 sporzadzony przez ORE na zlecenie MEN, Warszawa 2011, http://www.ore.edu.pl/phocadownload/edukacja_jezykowa/raport\%20polsko-niemiecki_all1.pdf [dostęp: 21 grudnia 2014]. 
Nauczanie języka niemieckiego jako języka mniejszości narodowej rozpoczęto na terenie województwa opolskiego w 1992 roku $^{15}$. Wcześniej, bo już w roku szkolnym 1990/1991 zorganizowano naukę języka niemieckiego jako obcego dla 5450 uczniów w 184 szkołach podstawowych, co stanowiło 30\% szkół w województwie. Poprzednio nauka języka niemieckiego jako obcego możliwa była tylko na poziomie szkoły średniej i de facto takie nauczanie prowadzono tylko na obszarach zamieszkałych przez ludność napływową ${ }^{16}$. Utrudniony dostęp do nauki języka niemieckiego w szkołach, nauczanego czy to jako język ojczysty, czy obcy, a z drugiej strony posługiwanie się w codziennych kontaktach gwarą śląską spowodowało, iż tylko najstarsze pokolenie Ślązaków znało ten język i tylko 6,5\% deklarowało, że posługuje się na co dzień językiem niemieckim. W pierwszej połowie lat dziewięćdziesiątych wprowadzanie języka niemieckiego do szkół jako języka ojczystego wywołało głosy protestu, że sprzyja to germanizacji polskojęzycznych Ślązaków. Rodzice nie kryli silnych obaw związanych ze złożeniem wniosku o nauczanie języka niemieckiego. Przede wszystkim postrzegano to jako deklarację narodowościowa, stąd też obawiano się szykan ze strony nauczycieli. Obawiano się także zbyt dużego obciążenia dzieci nauką języka niemieckiego w sytuacji, gdy w domu posługiwano się

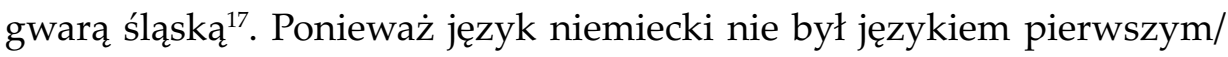
ojczystym, a de facto językiem obcym, miał być nauczany od klasy I, a nie jak w przypadku języka obcego od ówczesnej klasy V, co rodziło obawy, czy dzieci poradzą sobie z nauką.

15 Zob. szerzej: B. Gramlewicz, J. Stanek, Ksztatcenie dzieci mniejszości niemieckiej na Ślasku, w: J. Sztumski (red.), Badania nad sytuacją mniejszości niemieckiej na Śląsku po 1989 roku, Katowice 1999, s. 75-95. Na temat stanu nauczania języka niemieckiego w kolejnych latach: Kuratorium Oświaty w Opolu, Nauczanie języka niemieckiego jako języka mniejszości narodowej w szkołach woj. opolskiego, Opole, luty 2012, https://www.kuratorium.opole.pl/ wwse/nauczanie_jezyka_mniejszosci_raport.pdf.data [dostęp: 21 grudnia 2014].

${ }_{16}$ M. Lis, Ujawniona w 1989 roku mniejszość niemiecka na Ślasku Opolskim, "Przegląd Humanistyczny” 2000 nr 5, s. 85; A. Popiołek, Nauczanie języka niemieckiego w szkołach województwa opolskiego, w: M. Lis (red.), Polacy i Niemcy. Płaszczyzny i drogi normalizacji. Duszpasterstwo i szkolnictwo. Materiaty z sympozjum odbytego w Opolu w dniach 14-16 października 1993 r., Opole 1993, s. 39.

17 D. Berlińska, P. Madajczyk, Mniejszość niemiecka w Polsce, w: B. Berdychowska (red.), Mniejszości narodowe w Polsce. Praktyka po 1989 roku, Warszawa 1998, s. 117; D. Berlińska, Realizacja postanowień traktatu polsko-niemieckiego o dobrym sąsiedztwie i przyjaznej wspótpracy w kontekście praw człowieka, w: M. Lis (red.) Polacy i Niemcy..., s. 88-89. 
Według danych pochodzących z Systemu Informacji Oświatowej w roku szkolnym 2013/2014 na ogółem 65675 uczniów korzystających z nauki języka mniejszości lub w języku mniejszości języka niemieckiego uczyło się 40809 uczniów, co stanowiło 62,13\%. Na poziomie szkół podstawowych było to odpowiednio 61,63\% (27 650 uczniów wobec 44861 ogółem), a gimnazjów ponad 50\%. Na poziomie szkół ponadgimnazjalnych liczba uczniów była znikoma (zob. tabela 2).

\section{Tabela 2}

Liczba uczniów uczęszczających na zajęcia z języka mniejszości narodowej lub etnicznej, lub regionalnego według typów szkół w roku szkolnym 2013/2014

\begin{tabular}{|c|c|c|c|c|c|c|c|c|c|c|c|}
\hline \multirow[b]{2}{*}{ Typy jednostek } & \multicolumn{10}{|c|}{ Język mniejszości narodowej } & \multirow[b]{2}{*}{ Razem } \\
\hline & $\begin{array}{l}\overrightarrow{\vec{v}} \\
\frac{0}{0} \\
\overline{0} \\
\frac{\pi}{0} \\
.0\end{array}$ & 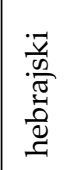 & 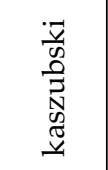 & 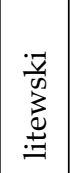 & 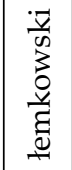 & 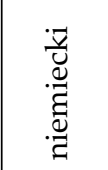 & 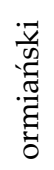 & $\begin{array}{l}\vec{v} \\
\overrightarrow{0} \\
\frac{\pi}{3} \\
\frac{0}{\omega}\end{array}$ & 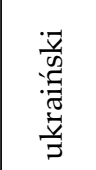 & 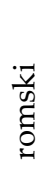 & \\
\hline $\begin{array}{l}\text { Przedszkole/ } \\
\text { oddział } \\
\text { przedszkolny } \\
\text { w szkole } \\
\text { podstawowej }\end{array}$ & 121 & 130 & 653 & 126 & 66 & 7259 & 2 & 181 & 336 & 0 & 8874 \\
\hline Szkoła podstawowa & 1610 & 205 & 13205 & 276 & 209 & 27650 & 49 & 139 & 1518 & 0 & 44861 \\
\hline Gimnazjum & 731 & 34 & 2682 & 143 & 65 & 5712 & 0 & 13 & 620 & 0 & 10000 \\
\hline $\begin{array}{l}\text { Zasadnicza szkoła } \\
\text { zawodowa }\end{array}$ & 0 & 0 & 83 & 0 & 0 & 56 & 0 & 0 & 17 & 0 & 156 \\
\hline $\begin{array}{l}\text { Liceum } \\
\text { ogólnokształcące }\end{array}$ & 672 & 0 & 340 & 114 & 12 & 55 & 0 & 0 & 282 & 0 & 1475 \\
\hline Technikum & 0 & 0 & 184 & 5 & 0 & 77 & 0 & 0 & 34 & 0 & 300 \\
\hline $\begin{array}{l}\text { Sześcioletnia szkoła } \\
\text { muzyczna I stopnia }\end{array}$ & 0 & 0 & 0 & 0 & 0 & 0 & 0 & 0 & 0 & 2 & 2 \\
\hline $\begin{array}{l}\text { Policealna szkoła } \\
\text { artystyczna }\end{array}$ & 7 & 0 & 0 & 0 & 0 & 0 & 0 & 0 & 0 & 0 & 7 \\
\hline Razem & 3141 & 369 & 17147 & 664 & 352 & 40809 & 51 & 333 & 2807 & 2 & 65675 \\
\hline
\end{tabular}

Źródło: System Informacji Oświatowej - stan na dzień 30 września 2013 roku. 


\section{Kontrowersje wokół nauczania języka niemieckiego jako języka mniejszości}

Zarówno zasady organizacji, szczególnie kwestia składania wniosków o zorganizowanie nauki języka niemieckiego jako języka mniejszości, jak i sposób finansowania takiej nauki od początku sprawiały wiele trudności interpretacyjnych, a często także budziły kontrowersje. W 1994 roku zaproponowano zmianę rozporządzenia w sprawie organizacji kształcenia umożliwiającego podtrzymanie tożsamości narodowej. Zgodnie ze złożoną propozycją wnioski o wprowadzenie języka ojczystego do szkół miały być gromadzone w Towarzystwie Społeczno-Kulturalnym Niemców (TSKN). Związek Towarzystw Niemieckich interweniował w tej sprawie u Rzecznika Praw Obywatelskich. W odpowiedzi na zapytanie Biura Rzecznika dyrektor Gabinetu Ministra w MEN-ie stwierdził, że pozostawałoby to $\mathrm{w}$ sprzeczności z obowiązującymi normami prawnymi ${ }^{18}$.

W czerwcu 1994 roku Związek Niemieckich Stowarzyszeń Społeczno-Kulturalnych w Polsce w odezwie do rodziców podjął próbę zachęcenia ich do składania wniosków o objęcie ich dzieci dodatkową nauką języka niemieckiego jako ojczystego w wymiarze 3 godzin tygodniowo. W piśmie podkreślano, że wówczas takie nauczanie będzie wprowadzone od I klasy, a nie jak w przypadku języka obcego od klasy $\mathrm{V}^{19}$. Tego typu oddolne działania aktywistów mniejszościowych nie zawsze spotykały się z aprobatą władz. Na przykład w październiku tego samego roku Urząd Miejski w Jastrzębiu Zdroju wystosował telefonogram do dyrektorów szkół, w którym zabroniono rozpowszechniania wśród uczniów deklaracji i odezw do rodziców, które nie były sygnowane przez organ prowadzący, ministerstwo lub kuratorium. Podkreślono również, iż zbieranie jakichkolwiek deklaracji od rodziców i uczniów powinno się odbywać za zgodą organu prowadzącego lub nadzorującego szkołę ${ }^{20}$.

W 2006 roku, w trakcie prac nad „Strategią rozwoju oświaty mniejszości niemieckiej w Polsce", podczas posiedzenia Podzespołu ds. Edu-

18 D. Berlińska, P. Madajczyk, op. cit., s. 136.

19 Pismo Związku Niemieckich Stowarzyszeń Społeczno-Kulturalnych w Polsce do rodziców, Opole, czerwiec 1994 [kopia w posiadaniu autorki].

20 Telefonogram Urzędu Miejskiego w Jastrzębiu Zdroju do dyrektorów szkół, 6 października 1994 [kopia w posiadaniu autorki]. 
kacji Mniejszości Narodowych podniesiono również kwestię wniosków. Ze strony przedstawicieli samorządu terytorialnego i części dyrektorów szkół pojawiły się opinie, iż składanie deklaracji przez rodziców (lub uczniów po ukończeniu 16 roku życia) spowodowało, że dochodziło do sytuacji, w których pod wnioskami podpisywali się rodzice dzieci nienależących do mniejszości. Proponowano, aby decyzję o organizacji nauczania języka mniejszości w szkole oraz „przekonaniu” uczniów do uczestnictwa w nich "powierzyć w całości dyrektorowi szkoły”21.

W opinii MEN zapisy Rozporządzenia Ministra Edukacji Narodowej z dnia 26 lutego 2002 roku w sprawie podstawy programowej wychowania przedszkolnego oraz kształcenia ogólnego w poszczególnych typach szkół ${ }^{22}$ wyraźnie różnicowały cele i treści nauczania języka niemieckiego jako języka obcego i jako języka mniejszości narodowej oraz określały kryteria, jakie w obu przypadkach powinny spełniać programy nauczania języka. W rozporządzeniu wskazano również odmienne zadania szkoły w odniesieniu do uczniów należących do niemieckiej mniejszości narodowej i uczniów pochodzenia polskiego, uczących się języka niemieckiego jako obcego. Według MEN-u niejednoznaczność sformułowań występujących w przepisach oświatowych z lat dziewięćdziesiątych mogła powodować różne ich interpretacje. Wprowadzone zmiany w prawie oświatowym uwzględniły jako obowiązujące określenie przedmiotów $\mathrm{w}$ odniesieniu do języka niemieckiego - w zależności od formy nauczania - ,język obcy” lub ,język mniejszości narodowej”23.

Na problem braku rozróżnienia pomiędzy uczniami uczącymi się języka niemieckiego jako języka mniejszości i jako języka obcego zwrócono też uwagę w "Strategii rozwoju oświaty niemieckiej w Polsce”, przyjętej w marcu 2007 roku. Przede wszystkim podkreślono, iż porównanie danych przekazywanych przez GUS z informacjami uzyskiwanymi $\mathrm{w}$ ramach sprawowanego przez kuratoria oświaty nadzoru

${ }^{21}$ Protokót z X posiedzenia Podzespołu ds. Edukacji Mniejszości Narodowych - Opole, 24 maja 2006 roku.

${ }_{22}$ Dz.U. 2002, nr 51, poz. 458.

${ }_{23}$ Odpowiedź sekretarza stanu w Ministerstwie Edukacji Narodowej i Sportu - z upoważnienia ministra - na interpelację nr 5273 w sprawie koncepcji nauczania języka niemieckiego realizowanej w woj. opolskim z 4 listopada 2003 r., http://orka2.sejm.gov.pl/IZ4.nsf/main/51937586 [dostęp: 21 grudnia 2014]. 
pedagogicznego wykazało rozbieżności w liczbie uczniów korzystających z nauki języka niemieckiego jako języka mniejszości. Kontrole przeprowadzone przez Najwyższą Izbę Kontroli pokazały, iż niektóre organy prowadzące szkoły zgłaszały $\mathrm{w}$ arkuszach statystycznych S-15 wszystkich uczniów uczących się w danej szkole języka niemieckiego, bez rozróżniania, czy jest to nauka języka niemieckiego jako języka mniejszości narodowej, czy niemieckiego jako języka obcego. Wynikało to $\mathrm{z}$ faktu, że w szkołach tych w jednej grupie klasowej w tych samych zajęciach z języka niemieckiego uczestniczyli zarówno ci uczniowie, którzy złożyli wnioski w sprawie zorganizowania nauki języka mniejszości narodowej, jak i ci, którzy wybrali język niemiecki jako język obcy ${ }^{24}$.

Zgodnie z wytycznymi MEN-u z maja 2009 roku było możliwe, aby uczeń gimnazjum, który uczy się języka niemieckiego jako jednego z dwóch nowożytnych języków obcych, złożył jednocześnie pisemny wniosek $\mathrm{w}$ sprawie udziału $-\mathrm{w}$ ramach podtrzymywania swojej tożsamości narodowej - w zajęciach z języka niemieckiego jako języka mniejszości. W takiej sytuacji szkoła była zobowiązana zorganizować zajęcia z języka niemieckiego jako jednego z dwóch języków obcych nowożytnych (w ramach puli godzin przeznaczonych w ramowych planach na naukę języków obcych) i jednocześnie dla tych uczniów, którzy złożyli wnioski w sprawie udziału w zajęciach służących podtrzymywaniu ich tożsamości narodowej, powinna była zorganizować dodatkowe zajęcia z języka niemieckiego jako języka mniejszości narodowej, $\mathrm{w}$ dodatkowych godzinach określonych w przepisach rozporządzenia dotyczącego ramowych planów nauczania. Nauczanie języka niemieckiego jako obcego powinno było być realizowane według programu zgodnego z podstawą programową w części dotyczącej nowożytnego języka obcego. Natomiast nauczanie języka niemieckiego jako języka mniejszości powinno było być realizowane według odrębnego programu, zgodnego z podstawą programową w części dotyczącej języka mniejszości narodowej i etnicznej ${ }^{25}$.

24 Strategia rozwoju oświaty niemieckiej w Polsce, 12 marca 2007, http://mniejszosci.narodowe.mac.gov.pl/download/86/12965/2007.pdf, s. 7 [dostęp: 21 grudnia 2014].

25 Stanowisko Ministerstwa Edukacji Narodowej z dnia 7 maja 2009 r. - nauczanie języka mniejszości narodowej w gimnazjach, http://www.prawo.vulcan.edu.pl/przegladarka. asp?qdatprz=04-03-2011\&qindrodzaj=1\&qindid=1345 [dostęp: 21 grudnia 2014]. 
Trudno oszacować skalę korzystania z możliwości nauki języka niemieckiego organizowanej na zasadach przewidzianych dla języków mniejszości przez osoby de facto zainteresowane nauką języka obcego, aczkolwiek takie zjawisko występowało. Szczególnie znamienna jest w tym zakresie anonimowa opinia jednej z osób, która uczęszczała na lekcje języka niemieckiego: „Pamiętam, jak w gimnazjum mieliśmy opcjonalny niemiecki, który był realizowany za sprawą oświadczenia, że należymy do mniejszości ekhm... niemieckiej. Rodzice prawie całej klasy podpisali to oświadczenie tylko po to, abyśmy się mogli uczyć niemieckiego. Mało kto należał do takiej mniejszości, śmiem twierdzić, że w mojej klasie nikt. Efekt był taki, że w zderzeniu z tym niemiłym dla ucha językiem, nikt nie potrafił się jego nauczyć, to była prawdziwa katorga. W czasie lekcji cisnęła nam się na usta tylko rota"26.

W ostatnich latach najbardziej nabrzmiałą sytuacją konfliktową była sprawa szkoły w Kędzierzynie-Koźlu, przejętej przez Stowarzyszenie Oświatowe Koźle Rogi. Szkoła została wpisana do ewidencji szkół i placówek prowadzonych przez organy inne niż gmina Kędzierzyn-Koźle w dniu 1 sierpnia 2012 roku pod nazwą Publiczny Zespół Przedszkolno-Szkolny z nauczaniem w języku polskim i języku mniejszości w Kędzierzynie-Koźlu i rozpoczęła działalność we wrześniu 2012 roku $^{27}$. Sprawa szkoły odbiła się szerokim echem na łamach prasy. Przede wszystkim spór wzbudziła kwestia związana z ponownym złożeniem wniosków o objęcie uczniów nauczaniem języka niemieckiego jako języka mniejszości po przejęciu szkoły przez stowarzyszenie ${ }^{28}$.

26 Anonimowy komentarz z dnia 13 lutego 2014, godz. 13:39, użytkownik niezalogowany, do artykułu: Złóż wniosek - ucz się języka mniejszości narodowej, http://www.naszraciborz.pl/site/art/3-kultura-i-edukacja/0-/33323-zloz-wniosek---ucz-sie-jezyka-mniejszoscinarodowej.html [dostęp: 21 grudnia 2014].

27 Ewidencja szkót i placówek prowadzonych przez organy inne niż gmina Kędzierzyn-Koźle, http://www.static.mzoiwkk.pl/download//655/ewidencja-szkol-i-placowek.doc; Protokół Nr XXVII/12 z sesji Rady Miasta Kędzierzyn-Koźle odbytej w dniu 24 września 2012 r., http://www.kedzierzynkozle.pl/bip/index.php?t=210\&id=47423\&mode=a\&d=T [dostęp: 21 grudnia 2014].

${ }_{28}$ M. Kolemba, Polskie dzieci w niemieckiej szkole?; Cykl publikacji nt. kontrowersyjnych praktyk w Szkole Podstawowej nr 13 w Koźlu Rogach, 23 listopada 2012, http://gazetylokalne.pl/a/polskie-dzieci-w-niemieckiej-szkole-cykl-publikacj/print; L. Stański, Coraz gęstsza atmosfera wokót podstawówki w Kożlu rogach, 18 września 2012, http://www.tygodnik7dni. pl/coraz-gestsza-atmosfera-wokol-podstawowki-w-kozlu-rogach-2012,09,18.html; Spo- 
Pewne kontrowersje budzi także kwestia wysokości środków finansowych przekazywanych na nauczanie języka niemieckiego jako języka mniejszości narodowej poprzez część oświatową subwencji ogólnej. Większość tych środków kierowana była do organów prowadzących/ organizujących nauczanie języka niemieckiego jako języka mniejszości (w latach 2001-2004 - 65-75\%, zob. tabela 3), a w roku 2013 było to ponad $40 \%{ }^{29}$. Skala tego dofinansowania często zestawiania jest z wysokością środków przekazywanych przez państwo niemieckie na wsparcie Polaków i Polonii w Niemczech. W przekazach prasowych relacjonowano te kwestie w artykułach o znamiennych tytułach, np. Polska wydaje fortunę na edukację mniejszości narodowych! ${ }^{30}$, Mniejszość niemiecka traktuje Polskę jak "dojna krowę" szości niemieckiej na Opolszczyźnie. W tym samym czasie RFN wstrzymat wsparcie finansowe dla Poloni $i^{32}$. W dyskursie publicystycznym silnie

łeczność PSP nr 13, List otwarty w sprawie PSP nr 13, 1 lipca 2013, http://www.lokalna.com. pl/main.php?act=czyt\&artid=20693; T. Kapica, K. Ogiolda, Większość nauczycieli ze szkoty dwujęzycznej w Koźlu-Rogach straciła prace, 29 sierpnia 2013, http://www.nto.pl/apps/ pbcs.dll/article?AID=/20130829/POWIAT03/130829567; T. Kapica, Kuratorium: w szkole w Koźlu-Rogach złamano prawo, 13 września 2012, http://www.nto.pl/apps/pbcs.dll/ article?AID=/20120913/POWIAT03/120919710; G. Stępień, Szkoła w Rogach. Rodzice nie ufaja urzędnikom i stowarzyszeniu, 21 lutego 2012, http://lokalna24.pl/news/?act=one\&from= portal_news\&kind=miasto\&id=6853; J. Kalucki, Szkoły dla Niemców, 21 maja 2012, http:// www.rp.pl/artykul/535576,878786-Oplaca-sie-prowadzic-szkoly-dla-mnieszosci.html; Będzie postępowanie dyscyplinarne w sprawie dyrektor z Koźla Rogów, PAP, 24 września 2012; http://wiadomosci.wp.pl/kat,1342,title,Bedzie-postepowanie-dyscyplinarne-ws-dyrektor-z-Kozla-Rogow,wid,14953926,wiadomosc.html?ticaid=113873; J. Kałucki, Oświatowy blitzkrieg, 30 kwietnia 2014, http://dorzeczy.pl/id,3108/Oswiatowy-blitzkrieg.html [dostęp: 21 grudnia 2014].

29 Z danych MEN wynika, iż w 2013 roku w ramach subwencji oświatowej przekazano do samorządów prowadzących szkoły, w których uczą się dzieci z mniejszości niemieckiej, 121,3 mln zł na ogółem $281 \mathrm{mln}$ zł, co stanowiło ponad 43\% tych środków. Prawie 80 mln zł na edukację mniejszości trafiło do regionu, PAP, 8 lutego 2014, http://wiadomosci.onet.pl/opole/prawie-80-mln-zl-na-edukacje-mniejszosci-trafilo-do-regionu/vdn7s [dostęp: 21 grudnia 2014].

${ }^{30}$ Polska wydaje fortunę na edukacje mniejszości narodowych!, 8 stycznia 2013, „Niezależna Gazeta Obywatelska w Opolu", http://www.ngopole.p1/2013/01/18/polska-wydaje-fortune-naedukacje-mniejszosci-narodowych/ [dostęp: 21 grudnia 2014].

31 Mniejszość niemiecka traktuje Polskę jak „dojna krowę”, 18 stycznia 2013, „Bibuła. Pismo niezależne", http://www.bibula.com/?p=66735 [dostęp: 21 grudnia 2014].

${ }^{32}$ Polska przeznacza dziesiątki milionów dla mniejszości niemieckiej na Opolszczyźnie. W tym samym czasie RFN wstrzymat wsparcie finansowe dla Polonii, 8 lutego 2014, http:// wpolityce.pl/polityka/185133-polska-przeznacza-dziesiatki-milionow-dla-mniejszosci- 
eksponowana była zasada wzajemności, ale także np. w czasie debat sejmowych podnoszono tę kwestię ${ }^{33}$.

\section{Tabela 3}

Wysokość dodatkowych środków przekazanych w latach 2001-2004 dla uczniów z mniejszości narodowych i etnicznych poprzez część oświatową subwencji ogólnej (w zł)

\begin{tabular}{|c|c|c|c|c|c|}
\hline Rok & $\begin{array}{c}\text { Kwota } \\
\text { subwencji } \\
\text { oświatowej } \\
\text { naliczona } \\
\text { wagą „0,2” } \\
\text { dla uczniów } \\
\text { mniejszości } \\
\text { niemieckiej }\end{array}$ & $\begin{array}{c}\text { Kwota } \\
\text { subwencji } \\
\text { oświatowej } \\
\text { naliczona } \\
\text { wagą „0,5” } \\
\text { dla uczniów } \\
\text { mniejszości } \\
\text { niemieckiej }\end{array}$ & $\begin{array}{c}\text { Razem waga } \\
\text { 0,2 i 0,5 } \\
\text { dla uczniów } \\
\text { mniejszości } \\
\text { niemieckiej }\end{array}$ & $\begin{array}{c}\text { Kwota subwencji } \\
\text { oświatowej } \\
\text { ogółem naliczona } \\
\text { wagami „0,2” i „,0,5” } \\
\text { dla wszystkich } \\
\text { uczniów mniejszości } \\
\text { narodowych } \\
\text { i etnicznych }\end{array}$ & $\begin{array}{c}\text { \% środków } \\
\text { dla uczniów } \\
\text { mniejszości } \\
\text { niemieckiej } \\
\text { w stosunku } \\
\text { do ogółu } \\
\text { środków } \\
\text { dla mniejszości } \\
\text { narodowych } \\
\text { i etnicznych }\end{array}$ \\
\hline 2001 & 13207033 & - & 13207033 & 17530423 & 75,33 \\
\hline 2002 & 16016834 & 1346469 & 17363303 & 24641985 & 70,46 \\
\hline 2003 & 17234550 & 1450675 & 18685225 & 27192167 & 68,71 \\
\hline 2004 & 18270641 & 1636785 & 19907426 & 30616333 & 65,02 \\
\hline
\end{tabular}

Źródło: Strategia rozwoju oświaty niemieckiej w Polsce, 12 marca 2007, http://mniejszosci.narodowe.mac.gov.pl/download/86/12965/2007.pdf, s. 11 [dostęp: 21 grudnia 2014].

Podanie nieprawidłowej liczby uczniów pobierających naukę języka niemieckiego jako języka mniejszości, np. zawyżenie jej poprzez podanie ogółu uczniów uczących się języka niemieckiego jako obcego, powodowało konieczność zwrotu subwencji ${ }^{34}$. Jednak w tych przypadkach, w których rodzice, mimo braku poczucia tożsamości mniejszościowej, składają wnioski o objęcie ich dzieci nauką języka niemieckie-

niemieckiej-na-opolszczyznie-w-tym-samym-czasie-rfn-wstrzymal-wsparcie-finansowedla-polonii [dostęp: 21 grudnia 2014].

33 Stenogram z 92 posiedzenia Sejmu RP (3 kadencja) w dn. 30.11 .2000 r., 33 punkt porządku dziennego: pytania w sprawach bieżacych - poset Janusz Dobrosz, http://orka2.sejm.gov. pl/Debata3.nsf/main/25E13318 [dostęp: 21 grudnia 2014].

34 Zob. np.: Wyrok Wojewódzkiego Sądu Administracyjnego w Warszawie z dnia 18 kwietnia 2005 roku, sygn. III SA/Wa 1785/04; Wyrok NSA z 3 października 2005 roku, sygn. II GSK 163/05. 
go jako języka mniejszości, nie jest możliwa ich weryfikacja. Sprawia to, że mogą być wysuwane zarzuty o „wyłudzanie” środków z subwencji ${ }^{35}$.

\section{Działania na rzecz nauczania dwujęzycznego}

Organizacje mniejszości niemieckiej podejmują szereg pozytywnych działań na rzecz promowania dwujęzyczności, w szczególności Związek Niemieckich Stowarzyszeń Społeczno-Kulturalnych w Polsce ${ }^{36}$, ale także Dom Współpracy Polsko-Niemieckiej ${ }^{37}$. Przeprowadzona została kampania „Bilingua - łatwiej z niemieckim”. Powstała strona internetowa kampanii, jak również działa doradca ds. dwujęzyczności ${ }^{38}$. Prowadzona jest działalność wydawnicza promująca dwujęzyczność. Wydano publikacje o charakterze poradnikowym: Dwa języki podwójna szansa. Poradnik dla rodziców dzieci dorastajacych dwujęzycznie; Vademecum. Deutsch als Minderheitensprache in der Praxis, opracowane przez Waldemara Gaidę (także w języku polskim: Język niemiecki jako język mniejszości w praktyce). Wydawany jest polsko-niemiecki magazyn dla klas IV-VI „Keks”39 oraz dla młodzieży „Antidotum”40.

Przedstawiciele mniejszości niemieckiej rozmawiali na temat dwujęzycznego nauczania z reprezentantami samorządów i nauczycielami z Opolszczyzny w lutym 2013 roku w Regionalnym Centrum Rozwoju Edukacji podczas konferencji dotyczącej wspierania edukacji dzieci i młodzieży mniejszości niemieckiej oraz doskonalenia nauczycieli. Działacze mniejszości niemieckiej starali się zachęcić jednostki samorządu terytorialnego do zwiększenia zakresu nauczania dwujęzycznego w szkołach podstawowych, gimnazjach i szkołach ponadgimnazjalnych. Podkreślano przede wszystkim korzyści płynące z dwujęzycz-

35 J. Kałucki, Szkoły dla Niemców, 21 maja 2012, http://www.rp.pl/artykul/878786.html [dostęp: 21 grudnia 2014].

36 www.vdg.pl

37 www.haus.pl

38 www.bilingua.haus.pl

39 ISSN: 2300-5785.

40 ISSN: 1734-3364. Bezpłatny kwartalnik BJDM-u (BJDM - Bund der Jugend Deutschen Minderheit). 
nej edukacji, pozwalającej na lepsze opanowanie języka i promowanie wielokulturowości. Nauczanie dwujęzyczne odbywać się mogło na dwa sposoby. Pierwszy - gdy język niemiecki był traktowany w szkole jako język obcy i co najmniej dwa dowolne przedmioty nauczane są dwujęzycznie - w języku polskim i w języku niemieckim. Drugi sposób - przewidziany w przepisach o podtrzymywaniu tożsamości narodowej i etnicznej mniejszości - gdy język niemiecki jest nauczany jako język mniejszości narodowej, a więc zajęcia językowe wzbogacone są o treści związane z podtrzymywaniem tożsamości, a poza tym co najmniej cztery przedmioty nauczane są dwujęzycznie ${ }^{41}$. W dniu 20 marca 2013 roku w Opolu Dom Współpracy Polsko-Niemieckiej, wspólnie z Instytutem Goethego z Krakowa, zorganizował konferencję „Droga do polsko-niemieckiej dwujęzyczności - dobre przykłady z Europy”. Jej celem było podjęcie dyskusji na temat stanu realizacji dwujęzyczności polsko-niemieckiej w województwie opolskim ${ }^{42}$.

Także w programie wyborczym w trakcie kampanii przed wyborami samorządowymi jesienią 2014 roku znalazł się punkt dotyczący promowania dwujęzycznego szkolnictwa: „Nowoczesne, dwujęzyczne szkolnictwo przyszłością naszych dzieci”. Zapowiedziano podjęcie działań na rzecz dalszego rozwoju nauczania niemieckojęzycznego w szkołach i przedszkolach jako kontynuacja dwujęzyczności wyniesionej z domu i wprowadzenie do wielojęzyczności; powstanie dwujęzycznych klas w gimnazjach jako konsekwencji kształcenia niemieckojęzycznego; po-

${ }^{41}$ Opolscy Niemcy chca więcej nauczania dwujęzycznego, 4 lutego 2013, PAP, http://www. nto.pl/apps/pbcs.dll/article?AID=/20130204/POWIAT01/130209826; Mniejszość niemiecka chce więcej, 4 lutego 2013, http://niezalezna.pl/38076-mniejszosc-niemiecka-chce-wiecej; także: Ł. Biły, Oświata dla mniejszości - jest potrzeba, nie ma sposobu?, 5 kwietnia 2013, http:// www.eid.edu.pl/news/oswiata_dla_mniejszosci_-_jest_potrzeba_nie_ma_sposobu,1744. html? source=rss; Szkolnictwo $w$ Polsce. Chcq nauczyć po polsku i po niemiecku, 20 marca 2013, http://news.money.pl/artykul/szkolnictwo;w;polsce;chca;nauczyc;po;polsku;i;po;niemiecku,220, 0,1272284.html; Nowy rok szkolny: Mniejszość Niemiecka liczy na promocję dwujęzyczności. Informacja prasowa Zwiazku Niemieckich Stowarzyszeń Społeczno-Kulturalnych w Polsce (VDG), Opole, 30 sierpnia 2012, http://www.dfk-ratibor.pl/pl/wydarzenie/227 [dostęp: 21 grudnia 2014]; Dwujęzyczna szkoła tylko o krok, „Heimat. Mała Ojczyzna. Tygodnik Niemców na Śląsku Opolskim", 30 kwietnia - 1 maja 2014, s. 1.

${ }_{2}$ Dwujęzyczność w polskich szkołach, PAP, 21 marca 2013, http://szkola.wp.pl/ kat,131914,title,Dwujezycznosc-w-polskich-szkolach, wid,15432790,wiadomosc. html?ticaid=113b5c\&_ticrsn=3 [dostęp: 21 grudnia 2014]. 
wołanie niemieckojęzycznego centrum edukacji, które ma służyć poprawie standardów nauczania języka niemieckiego jako języka mniejszości narodowej ${ }^{43}$.

\section{Uwagi końcowe}

Analiza problematyki nauczania języka niemieckiego jako języka mniejszości narodowej w polskim systemie edukacji wskazuje na szereg problemów związanych $\mathrm{z}$ organizacją takiego nauczania zarówno w latach dziewięćdziesiątych XX wieku - bezpośrednio po wprowadzeniu takiej możliwości, jak i obecnie - po ponad dwóch dekadach organizowania nauki języka niemieckiego jako ojczystego, a więc mającej służyć podtrzymywaniu tożsamości narodowej. Główne problemy dotyczyły interpretacji zasad organizowania takiej nauki i rozróżnienia między nauką języka niemieckiego jako obcego i jako ojczystego mniejszości narodowej, tak w kwestiach organizacyjnych, jak i metodyczno-programowych. Problematyczny okazał się także sposób finansowania nauki języka niemieckiego jako języka mniejszości - tu przede wszystkim trzeba wymienić zawyżanie subwencji przez podawanie liczby wszystkich uczniów uczących się języka niemieckiego jako obcego oraz kwestie wysokości tych środków w porównaniu z poziomem wsparcia finansowego Polonii i Polaków w Niemczech ze środków publicznych.

Jak wspomniano na wstępie, we wrześniu 2014 roku duże kontrowersje wywołał artykuł opublikowany na łamach „Rzeczpospolitej” o znamiennym tytule Volkslista w szkole na Opolszczyźnie?, którego autor postawił tezę, iż Polacy mają dodatkowe lekcje niemieckiego, jeśli podpiszą deklarację, że należą do mniejszości ${ }^{44}$. Środowisko mniejszości niemieckiej w odpowiedzi na ten artykuł wystosowało list otwarty. Przewodniczący Związku Niemieckich Stowarzyszeń Społeczno-Kulturalnych w Polsce Bernard Gaida podkreślił, iż udział w takich zajęciach związany jest $\mathrm{z}$ subiektywnie odczuwanym poczuciem własnej

43 Komitet Wyborczy Wyborców Mniejszość Niemiecka, Akcenty programowe, b. d., http://mniejszoscniemiecka.eu/program-wyborczy-2014 [dostęp: 21 grudnia 2014].

44 A. Grabek, Volkslista w szkole na Opolszczyźnie?, 18 września 2014, http://www. rp.pl/artykul/1142024.html [dostęp: 21 grudnia 2014]. 
odrębności i przynależności do danego kręgu kulturowego i nie wymaga składania deklaracji narodowościowej ${ }^{45}$. Pokazuje to, iż kwestia składania wniosków o objęcie uczniów nauką języka niemieckiego jako języka mniejszości wzbudza w dalszym ciągu spory i konflikty. Trudno przewidzieć, czy (i na ile) podejmowane obecnie działania na rzecz promowania dwujęzyczności osłabią te konflikty w przyszłości.

\section{Abstract \\ Controversy Surrounding the Teaching of German as a Language of a National Minority in Poland after 1989 - Maintaining National Identity or Learning a Language}

This article attempts to analyse the problems of teaching German in Poland as a language of a national minority. According to the Polish law, the aim of such language classes is to maintain the national identity. As early as in the 90s of the twentieth century, however, when people were allowed to learn German as a minority language, there were allegations that some of them would send their children to these lessons without feeling de facto any relation to the German minority; they just wanted their children to learn a foreign language. During more than two decades of teaching German as a minority language, a number of interpretation problems appeared in the Polish education system concerning the principles of this teaching and persons entitled to receive education in this form. Applications for the admission of children to a German language course are treated as a declaration of nationality. A controversy also arises about the amount of additional financial resources provided for the organization of the minority language classes from the educational part of the general subsidy that is often compared to the funds allocated by the German authorities on the activities of the Polish diaspora and Poles in Germany. At present, the German minority in the Opole region undertakes a number of activities to promote bilingualism and thus overcome the conflicts around the German language, and to draw attention to the benefits of knowing more than one language as a first/ second language, and not just as a foreign language.

45 List otwarty do redakcji dziennika „Rzeczpospolita” Bernarda Gaidy - Przewodniczącego Związku Niemieckich Stowarzyszeń Społeczno-Kulturalnych w Polsce, 19 września 2014, http://www.vdg.pl/pl/article/2165-list-otwarty-do-redakcji-dziennikarzeczpospolita [dostęp: 21 grudnia 2014]. 